\title{
Window Opening Effects on Structural Behavior of Historical Masonry Fatih Mosque
}

\author{
Alemdar BAYRAKTAR ${ }^{1}$ Emin HÖKELEKLİ ${ }^{2}$ Temel TÜRKER ${ }^{3}$ \\ İsmet ÇALIK ${ }^{4}$ Ashraf ASHOUR ${ }^{5}$ Ayman MOSALLAM $^{6}$
}

\begin{abstract}
Structural walls of old historical structures are either blind or have openings for functional requirements. It is well known that in and out of plane responses of structural walls are affected by the size, locations and arrangements of such openings. The purpose of this investigation is to study the window opening effects on static and seismic behaviors of historical masonry old mosques. Fatih Mosque, which was converted from a church, constructed in 914 in Trabzon, Turkey is selected for this purpose. The mosque is being restored. Structural exterior walls of the mosque were made using stone and mortar materials. When the plaster on the walls was removed during the restoration, 12 window openings were found as blind on the exterior structural walls of the mosque. Within the scope of restoration works, it is aimed to open such blind windows. In order to investigate the effects of the window openings on the structural behavior of the mosque, 3D solid and finite elements models of the mosque with and without window openings are initially developed. The experimental dynamic characteristics such as frequency, damping ratio and mode shapes of the current situation of the mosque, where some windows openings are blind, are determined using Ambient Vibration Testing. Then, the finite element model of the current situation of the mosque is updated using the experimental dynamic characteristics. The static and seismic time history analyses of the updated finite element model with and without window openings are carried out. Structural behaviors of the mosque with and without window openings are compared considering displacement and stress propagations.
\end{abstract}

Keywords: Window openings, Structural walls, Historical masonry mosque and church, Ambient vibration testing, Structural assesment

\footnotetext{
${ }^{1}$ Corresponding Author, Emeritus Professor, Turkey, Scopus Id: 6602269704, alemdarbayraktar@gmail.com

${ }^{2}$ Ass. Prof., Bartın University, Bartın, Turkey, emin hokelekli@hotmail.com

${ }^{3}$ Assoc. Prof., Karadeniz Technical University, Trabzon, Turkey, temelturker@hotmail.com

${ }^{4}$ Dr., Directorate Regional of Foundations, Erzurum, Turkey, ismetcalik@yahoo.com

${ }^{5}$ Professor, University of Bradford, Bradford, West Yorkshire, UK, Scopus Id: 7005633555, A.F.Ashour@bradford.ac.uk

${ }^{6}$ Professor, University of California, Irvine, USA, mosallam@uci.edu
} 


\section{Introduction}

Masonry old historical religious structures such as mosques and churches are impotant part of the world cultural heritage. They must be safely restored and passed to future generations in a good state. As the structural elements are composed of domes, vaults, transition elements, arches, counterweight towers, piers, foundations, and walls with and without window openings, structural responses of historical masonry old mosques and churches represent a challenging task. Therefore, structural intervention to such historical structures should be decided according to the results of experimental and numerical studies.

Structural assessments of historical structures including non-destructive experimental and numerical analyses have attracted many researchers' attention over the past few decades. Berilgen (2007) evaluated local site effects on earthquake damages of Fatih Mosque in İstanbul, Turkey and demonstrated the considerable degree of site amplification was compatible with the recorded motions and the damage suffered. A Romanesque masonry church, a basilica-type church and basilica of Santa Maria all'Impruneta (Italy) were analysed by Betti and Vignoli (2008a; 2008b; 2011) in order to assess their structural behaviour and seismic vulnerability. Portioli et al. (2011) assessed the seismic behavior of Mustafa Pasha Mosque in Skopje and the efficiency of a CFRPbased strengthening technique. Linear dynamic and nonlinear static analyses were performed to design the retrofitting intervention and to analyze the seismic behavior of the large-scale model before and after strengthening. A seriously damaged single domed mosque of 16th century classical Ottoman architecture was investigated by Koseoglu (2011). Arêde et al. (2012) carried out the development of an integrated strategy for modelling, experimental calibration, numerical analysis and seismic strengthening of two churches of the Pico Island, Azores, namely the Bandeiras and the Madalena churches. Seismic performance of the St. Nicholas Cathedral that dates back to 1300 s was assessed and a number of rehabilitation recommendations were suggested 
by Cagnan (2012). Findings of this study suggested that it will sustain severe damage at its flying buttresses and flying buttress-vault connection points (part of the roof structure) under an earthquake of 475 year return period with the peak ground acceleration level of $0.29 g$. Lagomarsino (2012) evaluated the churches damaged in L'Aquila earthquake in 2009. The bad behaviour of churches strengthened by modern techniques such as the substitution of original timber roofs with stiff and heavy RC slabs was observed. The author emphasized that for a correct interpretation of damage and vulnerability of churches, a deep knowledge of local techniques and of the historic transformation sequence is necessary. Seker et al. (2014) investigated static and dynamic structural performance of a masonry domed mosque. They showed that the stresses calculated from dynamic analysis might cause structural problems in terms of tensile stresses. Çakır et al. (2015) implemented static and dynamic analyses of historical masonry Lala Pasha Mosque by experimental tests and finite element simulation. The results of the study showed that the most critical parts of the mosque are the dome, pulley, and the supports of the main arch structures that carry the main dome. Additionally, the dynamic analyses proved that the most critical parts of the mosque are the sub-sections of the main columns, the window edges, and small domes. Koseoglu and Canbay (2015) investigated a damaged single domed mosque of the 16th century classical Ottoman architecture and explored the reasons for the structural damage and proposed a rehabilitation method including mini-pile application to the firm soil (rock) in order to prevent soil displacement. Rossi, Cattari, and Lagomarsino (2015) implemented performancebased assessment of the Great Mosque of Algiers. The integrated use of different modeling strategies to provide a more reliable seismic performance based assessment of the mosque discussed by the authors; in particular, the use of a detailed model (finite element analysis with nonlinear constitutive laws for masonry) allowed, on the one hand, to improve the evaluation carried out through the nonlinear kinematic analysis (rigid macro-block model) and, on the other one, to calibrate the use of the 3D macro element model (equivalent frame approach) for predicting 
the response of the arcade structural system. Some deficiencies related to the conservation of the mihrâb were obtained and a strengthening intervention including the roof bracings was recommended. It was observed that the proposed intervention is effective in improving its seismic response. They generally stated that the advanced numerical analysis can offer significant information on the understanding of the actual structural behavior of historical structures. Demir et al. (2016) and Nohutcu et al. (2015) determined dynamic characteristics of Hafsa Sultan mosque in Manisa, Turkey by operational modal testing and investigated its seismic behavior. Milani and Valente (2015a; 2015b) performed nonlinear analyses of seven masonry churches in Italy severely damaged during the 2012 Emilia-Romagna earthquake. It was found that finite element limit analysis may provide reliable failure mechanisms - when compared with the other approaches such as manual kinematic limit analysis and finite element pushover analysis - but requiring a reduced processing time, without the need to adopt questionable a priori choices on the macroblocks active at collapse. Aslan and Sahin (2016) evaluated seismic behavior of Suleymaniye Mosque in Turkey under different earthquake records and determined the most affected areas of the structure. Tzanakis, Papagiannopoulos, and Hatzigeorgiou (2016) investigated the linear seismic behavior of St. Titus Church in Heraklion, Crete, Greece as well as the need of its seismic retrofitting. Altunişik, Bayraktar, and Genc (2016) determined seismic earthquake behaviour of Kaya Çelebi Mosque, which is located in Turkey. It was stated by the authors that the tensile stresses, especially between the stone and mortar, are very critical for the selected masonary mosques. Calık, Bayraktar, and Türker (2016) and Calık et al. (2017) determined the dynamic behaviour of historical masonry mosques with reinforced concrete domes before and after restoration using ambient vibration testing. Valente, Barbieri, and Biolzi (2017a) described the different phases of an integrated approach to obtain an accurate assessment of the structural damage and seismic performance of two masonry Baroque churches located in Northern Italy, which were affected by the 2012 Emilia earthquake. The numerical simulations led to the 
determination of damage distribution and the identification of the most vulnerable elements, highlighting the main structural deficiencies of the churches when subjected to different levels of seismic actions. Jorquera et al. (2017) investigated structural characterization and seismic performance of San Francisco Church, the Most Ancient Monument in Santiago, Chile. The results highlighted the particularities of the building and the current seismic vulnerabilities in order to provide a robust knowledge basis on which possibly pivoting future consolidation and safeguarding strategies could be done. Valente, Barbieri, and Biolzi (2017b) investigated the seismic behavior of three masonry churches in Northern Italy that were damaged by the 2012 Emilia earthquake. Non-linear dynamic analyses with different peak ground accelerations were performed and identified the damage patterns and the main collapse mechanisms for different seismic intensity levels. The results appear to be in a good agreement with the damage experienced by the churches during the earthquake. Karaton and Aksoy (2018) implemented seismic damage assessment of an 891 years old historic masonry mosque. Damage regions on the mosque under earthquake loads were determined and retrofitting suggestions were recommended.

The effects of opening of the blind windows have not been considered in the above studies. The effects of opening of the blind windows on the static and seismic structural responses of historical masonry stone old mosques having blind windows are investigated in this study. Fatih Mosque, which was converted from a church, constructed in 914 in Trabzon, Turkey is selected for this purpose. The mosque is being restored. Within the scope of restoration works, it is aimed to open blind window openings. 3D solid and finite element models of the mosque with and without window openings are initially developed. Then, experimental dynamic characteristics such as frequency, damping ratio and modal shapes of the current situation of the mosque, where some window openings are blind, are determined using Ambient Vibration Testing. Initial finite element model of the current situation of the mosque is updated using the experimental dynamic 
characteristics, and static and seismic structural responses of the updated finite element model with and without window opening are obtained.

\section{Historical Masonry Fatih Mosque}

Fatih Mosque was built as stone masonry in 914 in the city of Trabzon, Turkey. Although the construction date of the structure is unknown, it is estimated that it was built as a church in 914 . The church was built as a rectangular plan with a base area of approximately $795 \mathrm{~m}^{2}$. The church was converted to a mosque in 1461 , and its minaret was built adjacent to the corner of the mosque. Views of the mosque and its minaret are shown in Fig. 1.

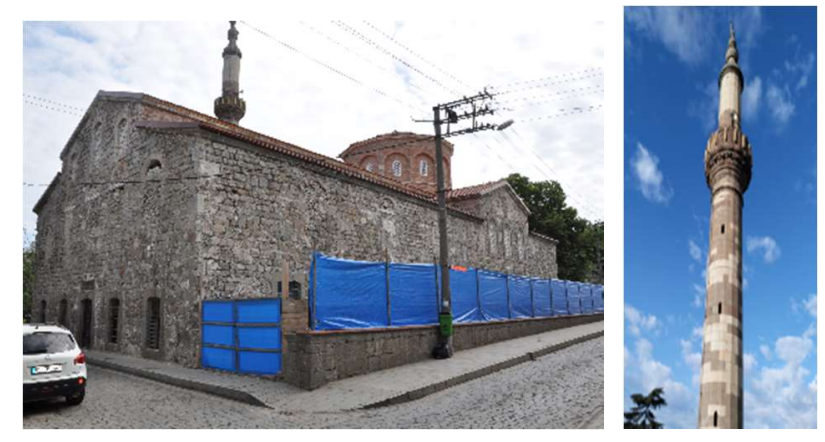

Fig. 1. Views of Fatih Mosque and its minaret

\subsection{Structural Properties of the Mosque}

Some views of the drawings prepared according to the data taken from laser scanning are given in

Fig. 2. The cylindrical minaret was built with a circular cross section. The mosque with rectangular plan consists of stone-bearing walls of approximately $1000 \mathrm{~mm}$ in thickness.
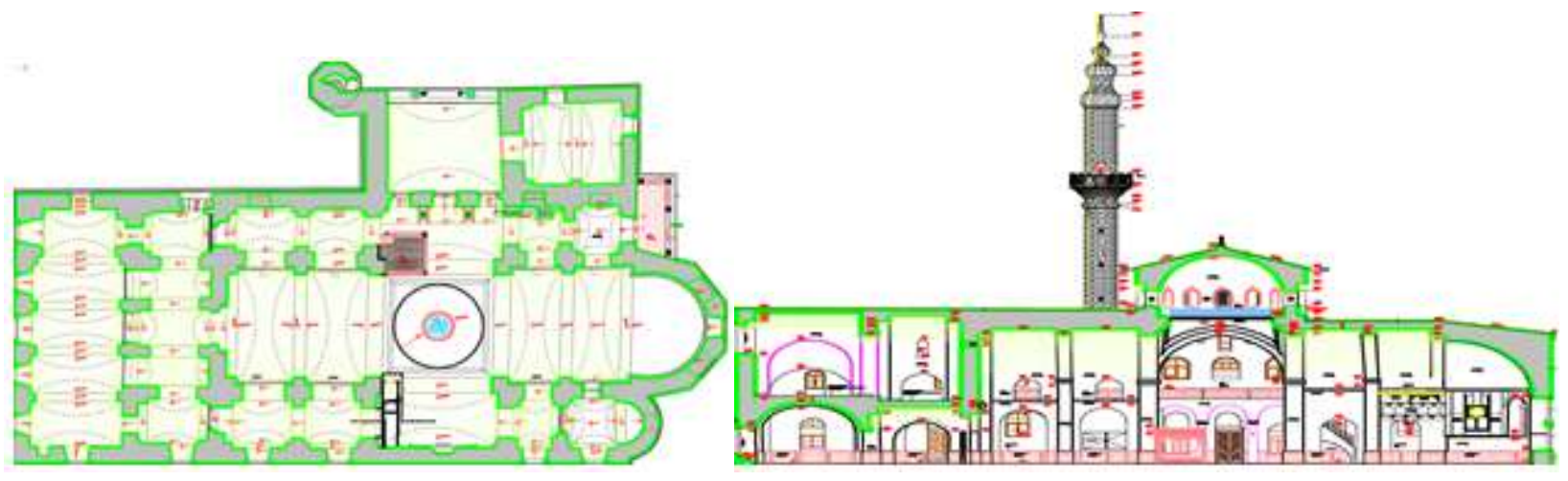

Fig. 2. Drawings of the mosque and its minaret (Restoration Project, 2014) 
Structural masonry walls of the mosque and minaret were built using andesite basalt stone and mortar. Brick and stone were used in the dome, vault and arches of Fatih Mosque. Properties of the structural wall stone and mortar used in the mosque were determined by Regional Directorate of Foundations in Trabzon, Turkey, and used in the current study. The content of the mortar and mechanical properties of the stone are given in Tables 1 and 2. The new mortar contents for the restoration were recommended as 33-35\% lime and $63-65 \%$ sand by the Regional Directorate of Foundations (Material Report (2013)). The average unit weight and compressive strength of the stone material used in the walls were obtained as $19.9 \mathrm{kN} / \mathrm{m}^{3}$ and $24.03 \mathrm{MPa}$, respectively. Considering the Turkish earthquake code (TDY (2007)), the load-bearing capacity and class of the soil near the mosque region were obtained from in-situ tests as $200 \mathrm{kN} / \mathrm{m}^{2}$ and $\mathrm{Z} 2$, respectively.

Table 1. The content of the mortar used in the walls of the mosque (Material Report (2013))

\begin{tabular}{|c|c|c|c|c|c|c|c|c|c|c|c|}
\hline \multirow{2}{*}{$\begin{array}{l}\text { Sample } \\
\text { Number }\end{array}$} & \multirow{2}{*}{$\begin{array}{c}\text { Acidic Loss } \\
\%\end{array}$} & \multicolumn{5}{|c|}{ Sieve Analyses (\%) } & \multicolumn{3}{|c|}{ Heating Loss } & \multicolumn{2}{|c|}{ Spot Tests } \\
\hline & & $1180 \mu$ & $600 \mu$ & $250 \mu$ & $125 \mu$ & $<125 \mu$ & \%Hum. & $\%$ Org. & $\% \mathrm{CaCO}_{3}$ & $\left(\mathrm{SO}_{4}\right)^{-2}$ & $\mathrm{CI}^{-}$ \\
\hline 1 & 33.17 & 1.40 & 7.90 & 50.21 & 29.76 & 10.72 & 0.18 & 4.98 & 22.15 & - & ++ \\
\hline 2 & 32.06 & 0.67 & 2.82 & 46.71 & 40.13 & 9.66 & 0.14 & 4.23 & 20.07 & - & ++ \\
\hline
\end{tabular}

Table 2. The mechanical properties of the stone used in the walls of the mosque (Material Report (2013))

\begin{tabular}{|c|c|c|c|c|c|c|c|c|}
\hline \multirow{2}{*}{$\begin{array}{l}\text { Sample } \\
\text { Number }\end{array}$} & \multirow{2}{*}{$\begin{array}{c}\text { Unit } \\
\text { Weight } \\
\left(\mathrm{g} / \mathrm{cm}^{3}\right)\end{array}$} & Diameter & Height & Area & $\begin{array}{l}\text { Failure } \\
\text { Load }\end{array}$ & \multicolumn{2}{|c|}{$\begin{array}{c}\text { Compressive } \\
\text { Strength }\end{array}$} & \multirow{2}{*}{$\begin{array}{l}\text { Stone } \\
\text { Class }\end{array}$} \\
\hline & & $(\mathrm{cm})$ & $(\mathrm{cm})$ & $\left(\mathrm{cm}^{2}\right)$ & (kgf) & $\left(\mathrm{kgf} / \mathrm{cm}^{2}\right)$ & (MPa) & \\
\hline $1(\mathrm{M}-1)$ & 1.83 & 5.15 & 10.30 & 20.82 & 3593 & 172.57 & 17.26 & Weak \\
\hline $2(\mathrm{M}-2)$ & 2.10 & 5.16 & 10.32 & 20.90 & 3638 & 269.75 & 26.97 & M.Weak \\
\hline 3 (M-3) & 1.90 & 5.16 & 10.32 & 20.90 & 4596 & 219.89 & 21.99 & Weak \\
\hline $4(\mathrm{C}-1)$ & 2.14 & 5.17 & 10.34 & 20.98 & 6121 & 296.49 & 29.65 & M.Weak \\
\hline $5(\mathrm{C}-2)$ & 2.13 & 5.16 & 10.32 & 20.90 & 7444 & 356.15 & 35.62 & M.Weak \\
\hline $6(\mathrm{C}-3)$ & 1.84 & 5.13 & 10.26 & 20.66 & 2626 & 127.21 & 12.72 & Weak \\
\hline
\end{tabular}

The earthquake zoning maps of Turkey and Trabzon city are shown in Fig. 3. Expected acceleration values for $1^{\text {st }}, 2^{\text {nd }}, 3^{\text {rd }}, 4^{\text {th }}$ and $5^{\text {th }}$ degree earthquake zones in Turkey are more than $0.4 \mathrm{~g}$, between $0.3 \mathrm{~g}-0.4 \mathrm{~g}$, between $0.2 \mathrm{~g}-0.3 \mathrm{~g}$, between $0.2 \mathrm{~g}-0.1 \mathrm{~g}$ and less than $0.1 \mathrm{~g}$ (where $\mathrm{g}$ 
is the gravity acceleration $=981 \mathrm{~cm} / \mathrm{s}^{2}$ ), respectively. Fatih Mosque is located in the city center of Trabzon. It can also be seen from Fig. 3 that Trabzon city is in 4th degree earthquake zone.

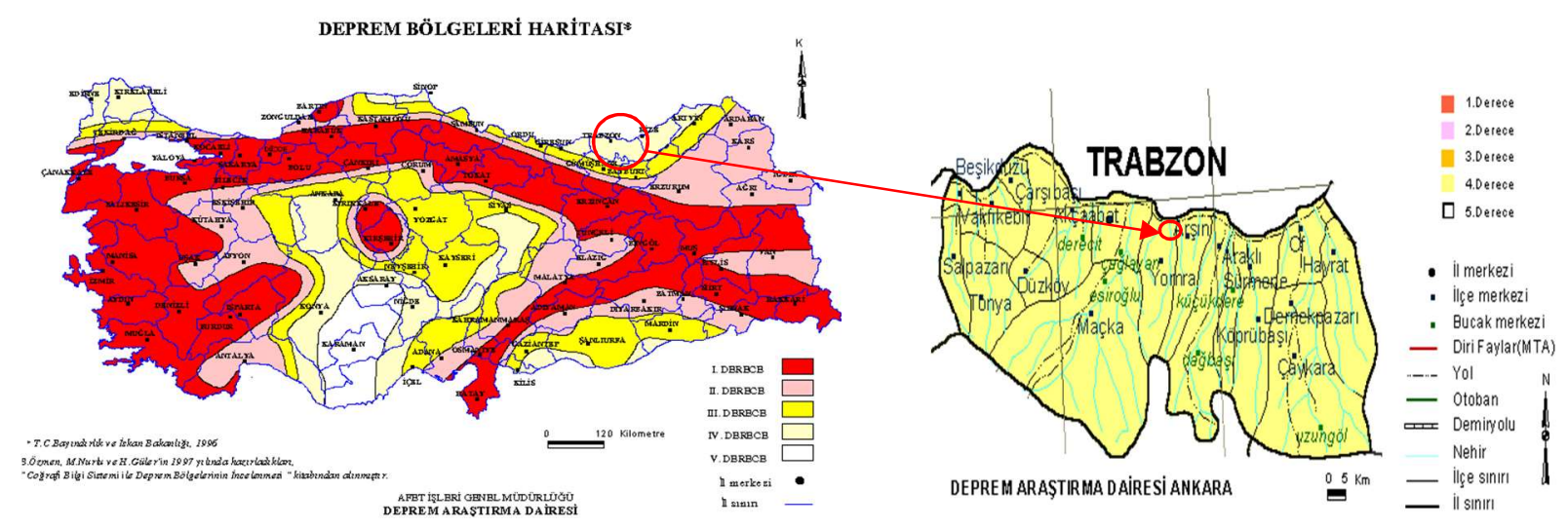

Fig. 3. Earthquake zoning maps of Turkey and Trabzon city (Web-1 (2017))

\subsection{Restoration Works of the Mosque}

It is understood from the art history report (Art History Report (2014)) that Fatih Mosque has undergone many repairs in the past and such restoration works are currently continuing. Within the scope of the restoration works, the plaster was removed, and the deterioration of the binder mortar, joint openings, deterioration in the wooden elements, cracks and moisture in the structural elements were observed (Fig. 4). In addition, as can be seen from Fig. 5, 12 previously window openings on the exterior structural walls were closed apparently to enhance the wall load bearing capacity. 

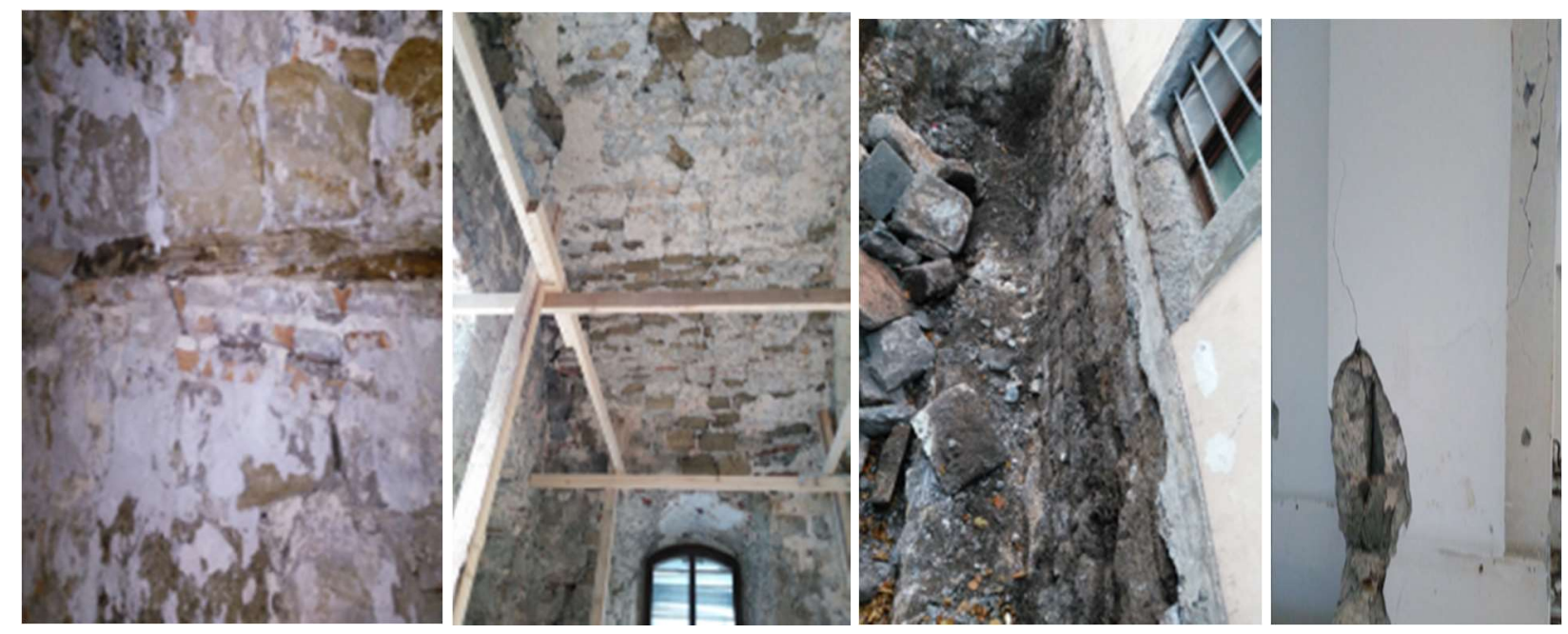

Fig. 4. Views from damages in the mosque
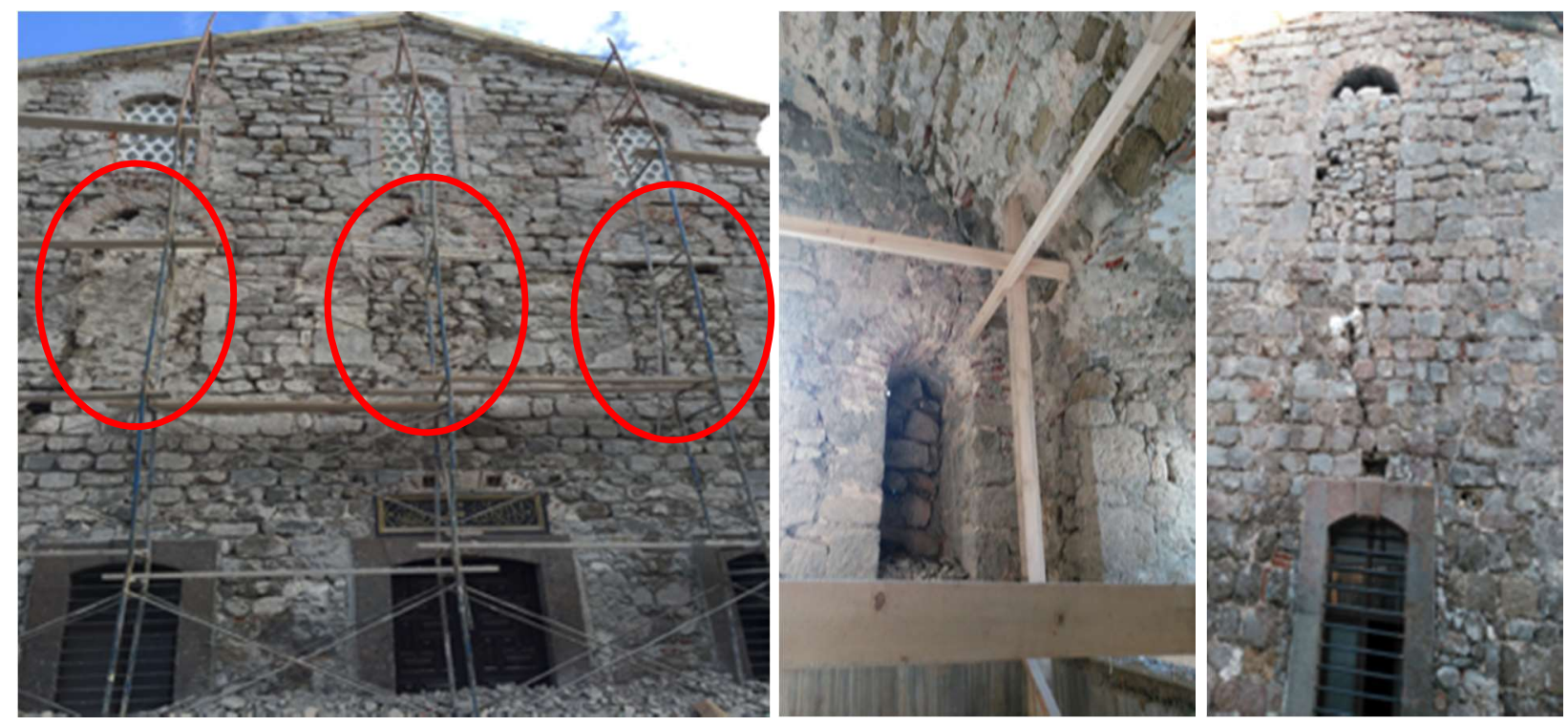

Fig. 5. Views of closed window openings on the exterior walls

\subsection{Structural Analysis of the Mosque}

Within the scope of restoration works, it is aimed to re-open the 12 blind windows. For this aim, static and seismic performances of the mosque without and with window openings are investigated below.

\subsubsection{Model Updating of the Mosque}

The three-dimensional solid models of Fatih Mosque prepared according to the restoration project and surveys are created without and with window openings separately as shown in Fig. 6 . As the 
minaret is located at the corner of the mosque, their effect on the stresses and strains in the mosque is expected to be minimum and, therefore, it is not considered in three-dimensional model of the mosque.
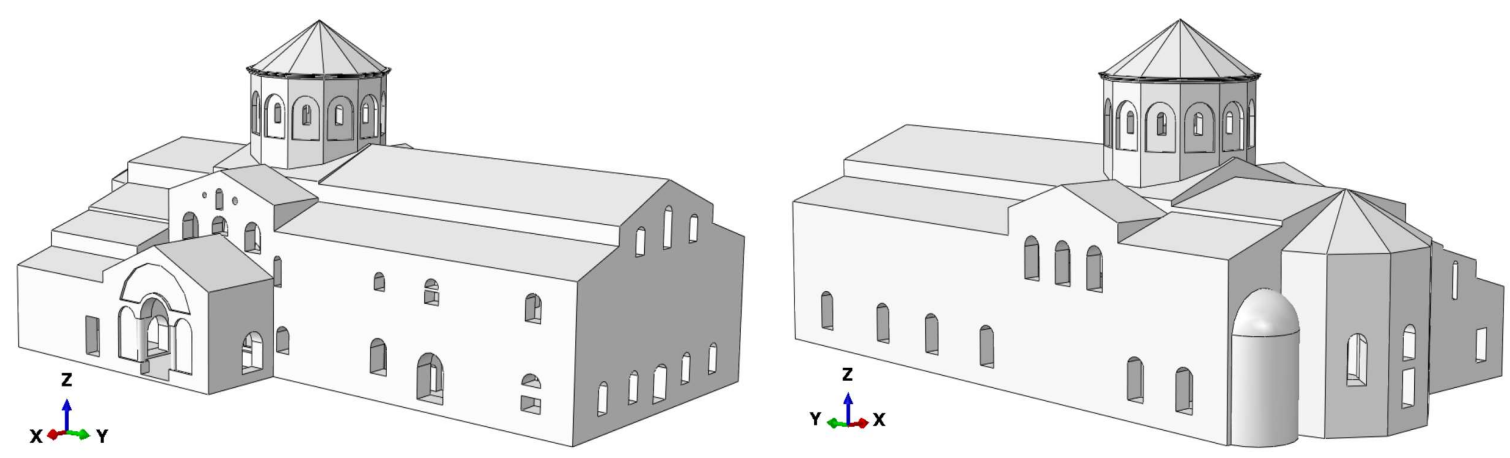

a) Without window openings

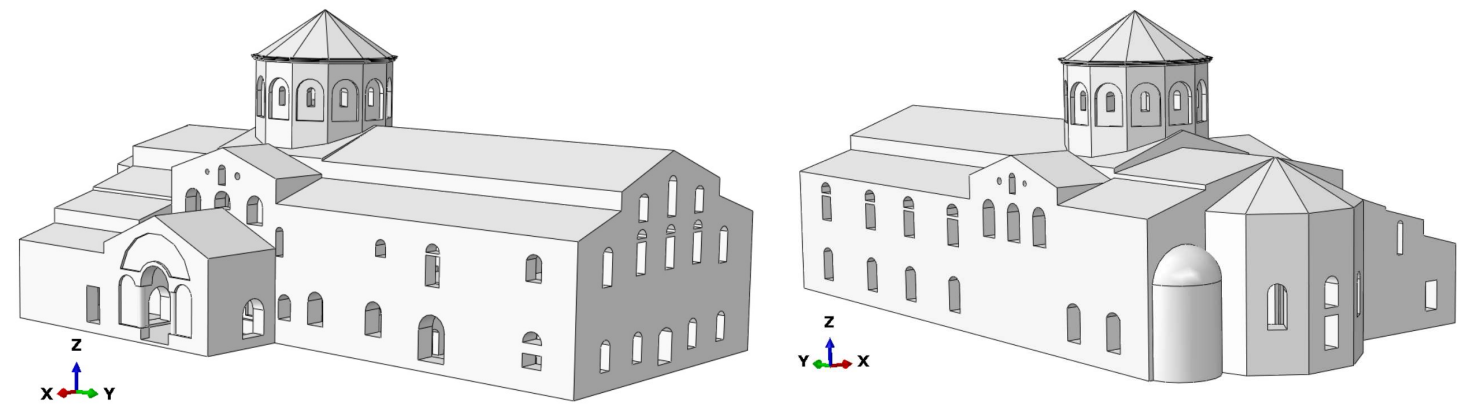

b) With window openings

Fig. 6. Solid models with and without window openings

The finite element models of the mosque without and with window opening are created using 249328 tetrahedral solid elements and 997312 nodal points, and 246344 tetrahedral solid elements and 954402 nodal points in Abaqus (2010), respectively. Three-dimensional finite element models of the mosque are given in Fig. 7. The mechanical properties of the masonry walls used in the current finite element model are obtained from the laboratory test as explained in Section 2.1 and the relations in Eurocode 6 (1996) are given in Table 3. The relation $\left(f_{k}=K f_{b}^{\alpha} f_{m}^{\beta}\right)$ in Eurocode 6 (1996) is used for the calculation of compressive strength of the masonry walls, and the values of $K, \alpha$ and $\beta$ are taken as $0.50,0.65$ and 0.25 , recpectively. Modulus of elasticity of masonry walls 
is taken as $1000 f_{k}$. According to Pluijm (2009), the tensile strength of masonry elements is generally less than $1 \mathrm{MPa}$. Therefore, the tensile strength of masonry walls of the mosque is assumed to be Regional Directorate of Foundations 10\% of the compressive strength.

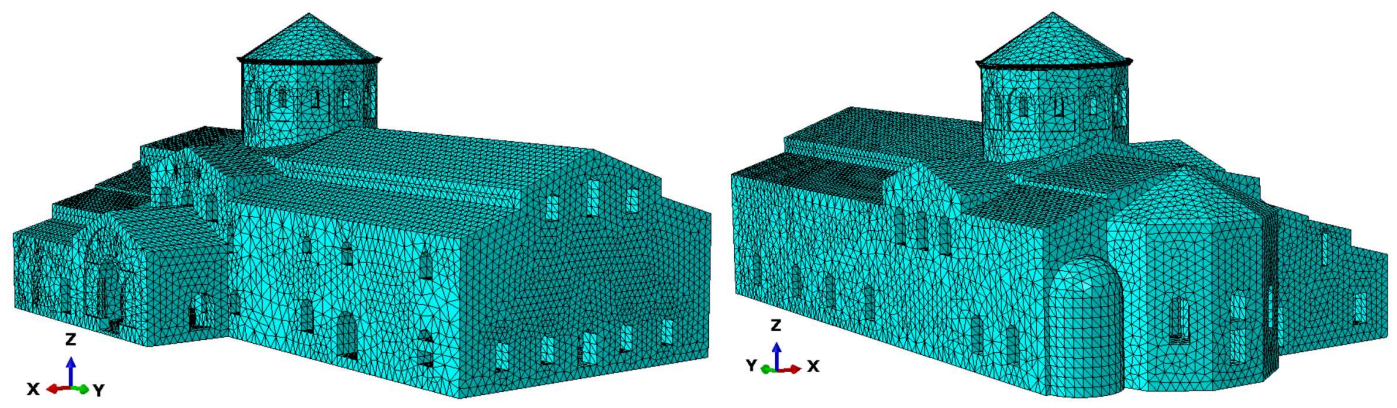

a) Without window openings
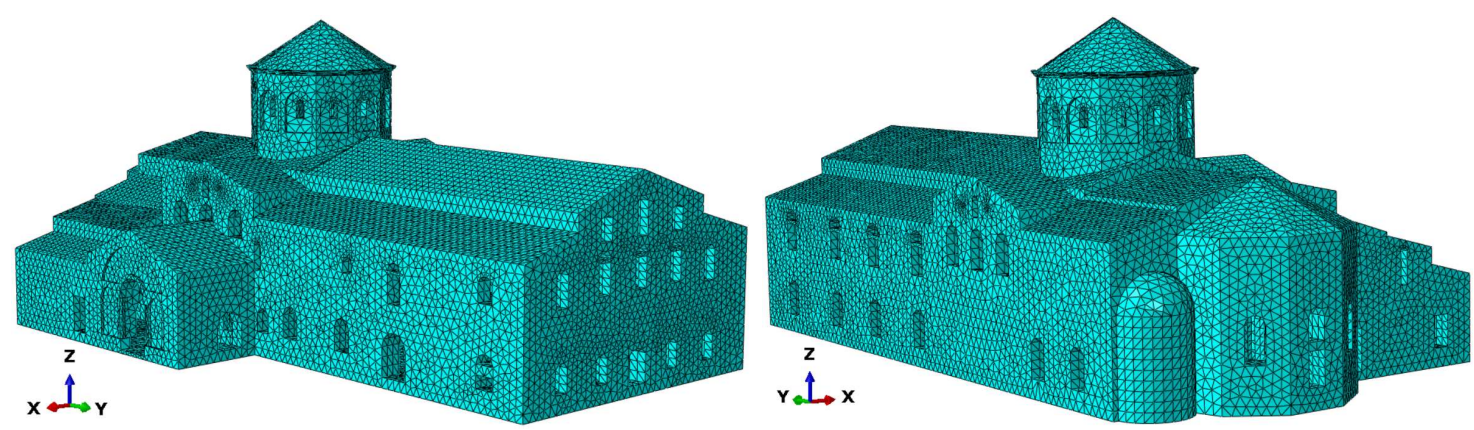

b) With window openings

Fig. 7. Finite element models with and without window openings

Table 3. Mechanical properties of masonry walls

\begin{tabular}{lll}
\hline \hline Properties & Stone wall & Brick wall \\
\hline Compressive Strength (MPa) & 6.11 & 2.82 \\
Tensile Strength (MPa) & 0.611 & 0.282 \\
Modulus of Elasticity (MPa) & 6110 & 2820 \\
Poisson's ratio & 0.17 & 0.20 \\
Density $\left(\mathrm{kg} / \mathrm{m}^{3}\right)$ & 2000 & 1780 \\
\hline \hline
\end{tabular}

Since the mosque is a complex structure, ambient vibration measurements were implemented on the mosque for initial calibration and validation of the finite element model. Experimental natural frequencies, mode shapes and modal damping ratios of Fatih Mosque are determined by Ambient 
Vibration Tests. Sensitive seismic accelerometers were used in the measurements. The signals from the accelerometers were collected with the help of the data logger unit and transferred to the computer. The images of accelerometer placement and dynamic measurements are given in Fig. 8. Frequency spectrum determined from the tests using Enhanced Frequency Domain Decomposition technique are given in Fig. 9.

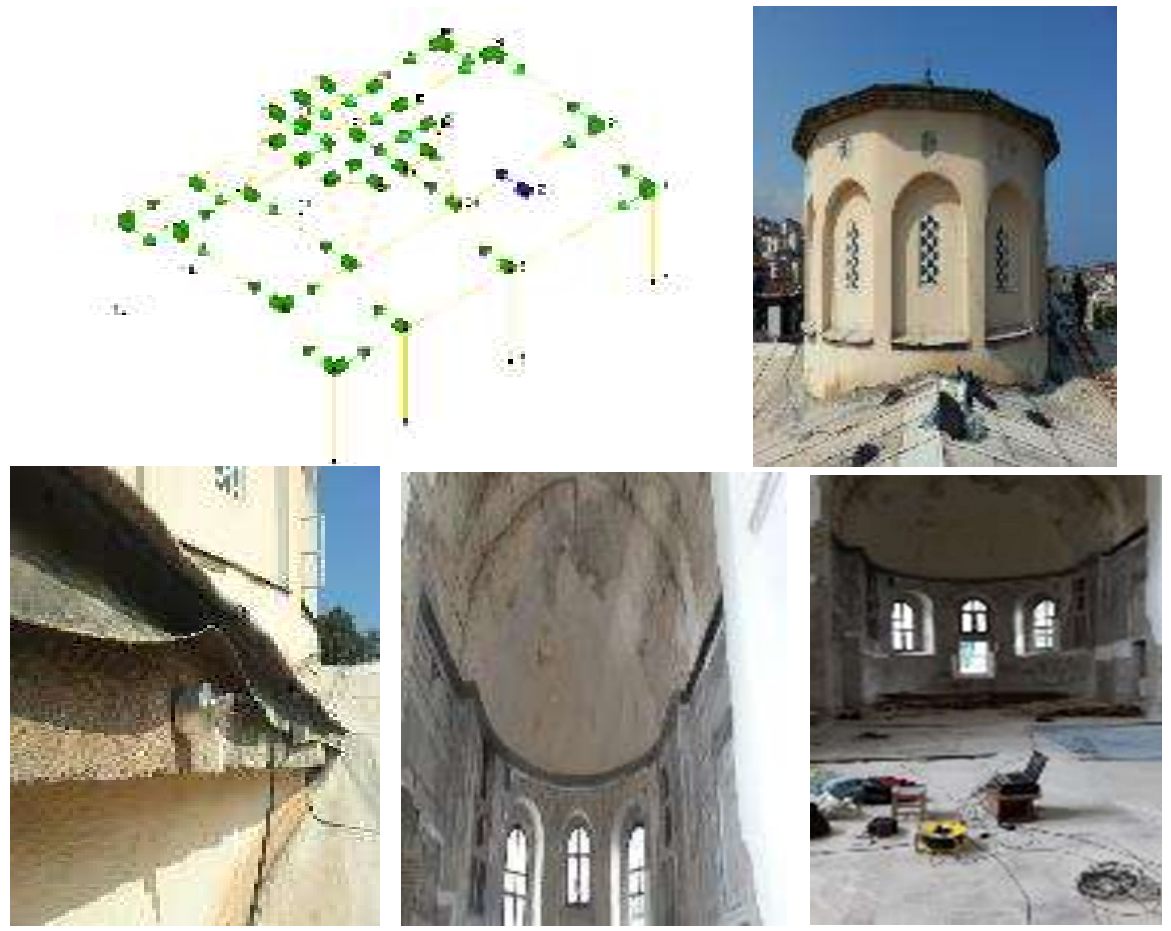

Fig. 8. Accelerometer layout and images from the measurements

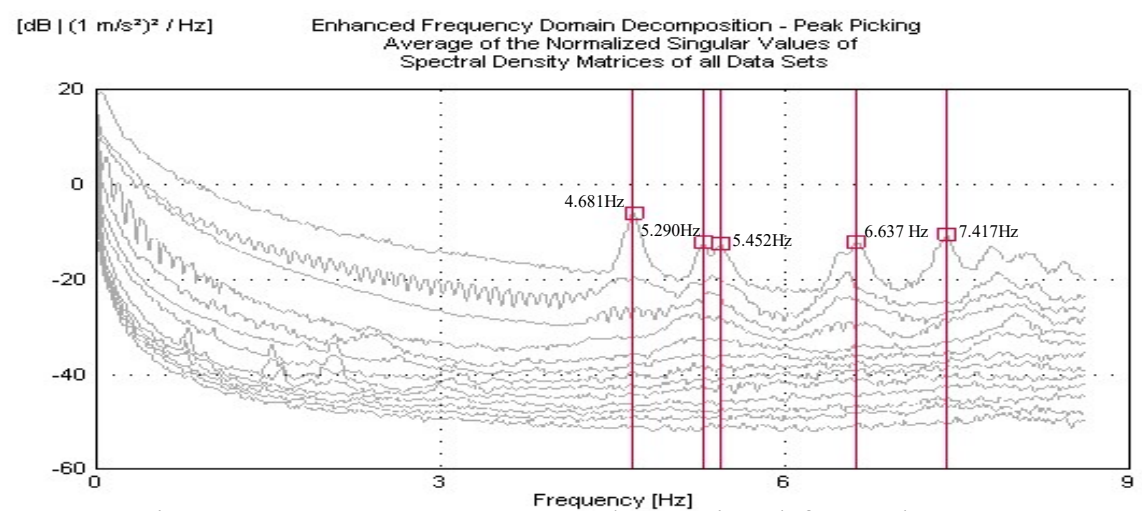

Fig. 9. Frequency spectrum determined from the tests 
The first 5 frequencies obtained from the initial finite element model of the mosque are given in Table 4. It can be seen from Table 4 that there are significant differences between the frequencies obtained from the initial finite element model and experimental tests. For this reason, initial finite element model of the mosque with blind window opening is updated by approximating the theoretical frequency values to the experimental frequency values. It is well known that historical masonry mosques and churches are complex structures having many elements and materials. The geometrical dimensions were more accurately measured than the material properties of the mosque, the material properties is likely to have wider variation from one point to another of various structural elements of the mosque. Therefore, the average material properties are only selected for the initial model calibration as the material properties of the mosque walls were determined only at six points given in Table 2 . The differences between the experimental and analytical frequencies after the model updating are greatly reduced, and the frequency values of the updated model with blind window opening are close to the experimental results as shown in Table 4. The experimental and updated theoretical mode shapes are given in Fig. 10. It can be seen from Fig.10 that the experimental and analytical mode shapes are compatible with each other. The updated finite element model with and without window opening are used in static and dynamic analyses.

Table 4. Initial and updated frequencies of the mosque with blind window opening

\begin{tabular}{ccccc}
\hline \hline Mode Number & Initial $(\mathrm{Hz})$ & Updated $(\mathrm{Hz})$ & Experimental $(\mathrm{Hz})$ & Difference (\%) \\
\hline 1 & 10.884 & 4.660 & 4.681 & 0.45 \\
2 & 12.876 & 5.506 & 5.290 & 4.08 \\
3 & 15.027 & 6.425 & 5.452 & 17.85 \\
4 & 16.886 & 7.254 & 6.637 & 9.30 \\
5 & 17.053 & 7.344 & 7.417 & 0.98 \\
\hline \hline
\end{tabular}



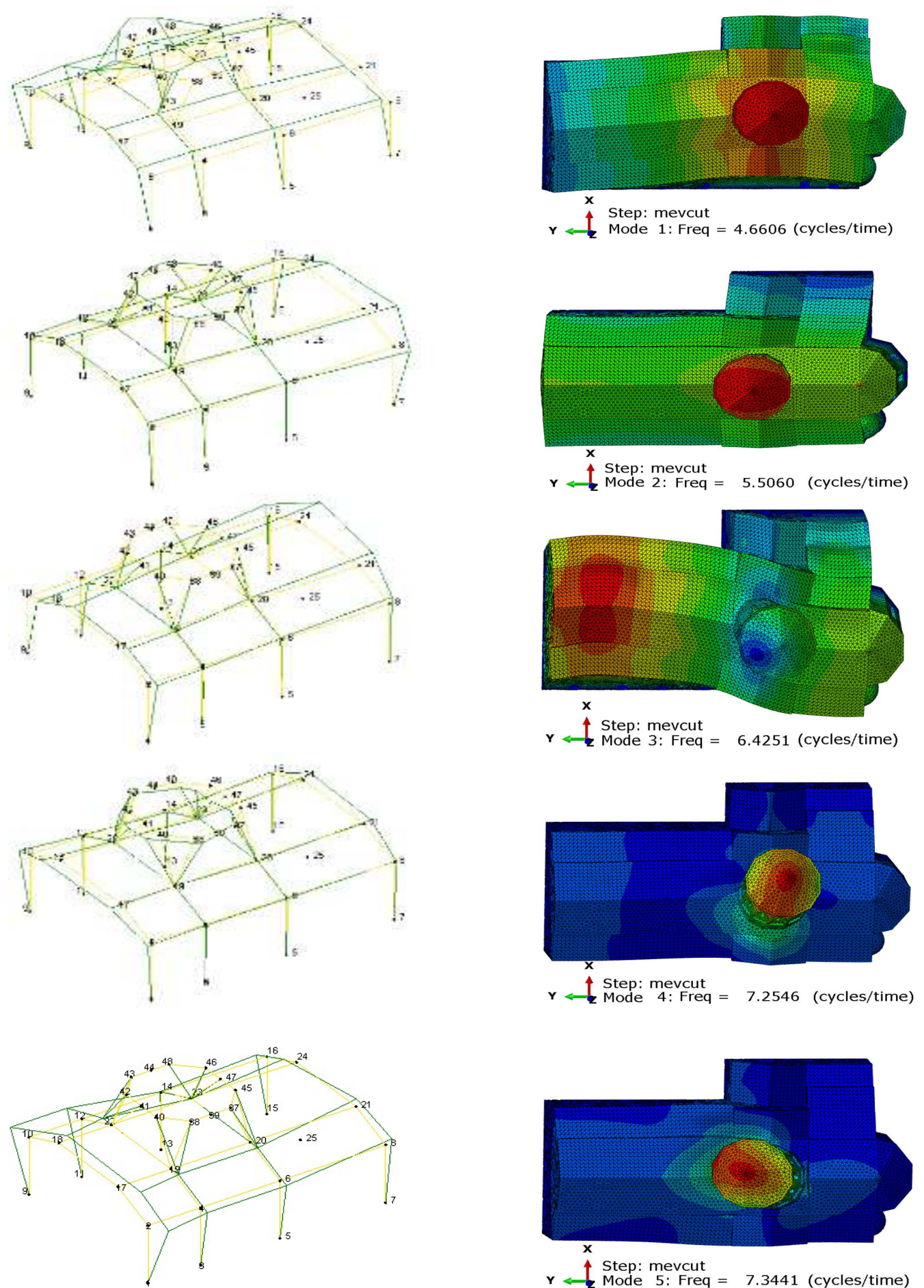

a) Experimental mode shapes

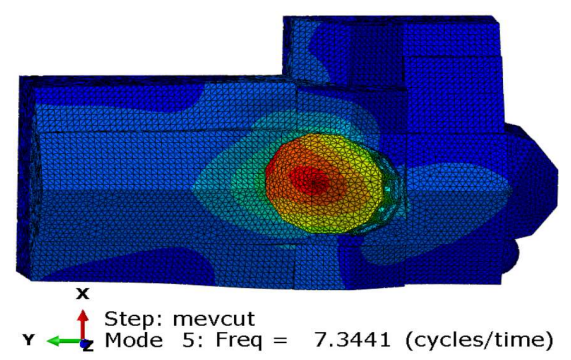

b) Analytical mode shapes

Fig. 10. Experimental and analytical mode shapes of the mosque

\subsubsection{Analysis of the Mosque with and without Window Openings}

Firstly, the static behavior of the mosque is investigated in cases of window opening are blind and open. The static analyses are carried out under the mosque's self weight and live loads. A live load 
of $5 \mathrm{kN} / \mathrm{m}^{2}$ is considered in the analysis as recommended for design of mosques in Turkish load stardard TS498 (1997). Fig. 11 shows the maximum static displacements and distributions of U1, $\mathrm{U} 2$ and U3 obtained in the transverse (X-axis), longitudinal (Y-axis) and vertical (Z-axis) directions from the finite element models with and without window opening. The maximum static vertical, transverse and longitudinal displacements are calculated as $5.84 \mathrm{~mm}, 1.65 \mathrm{~mm}$ and 0.85 $\mathrm{mm}$, respectively, in the case of blind window opening, whereas the corresponding values in the case of with window opening are $5.97 \mathrm{~mm}, 1.71 \mathrm{~mm}$ and $0.89 \mathrm{~mm}$, respectively. The above results indicate that the existence of the 12 windows has slightly increased the maximum static displacements. When the displacement propagations given in Fig. 11 are examined, the static displacements occuring in both cases of window opening generally shows similar behavior. It can be stated that opening of the blind windows slightly affects static behavior of the mosque.
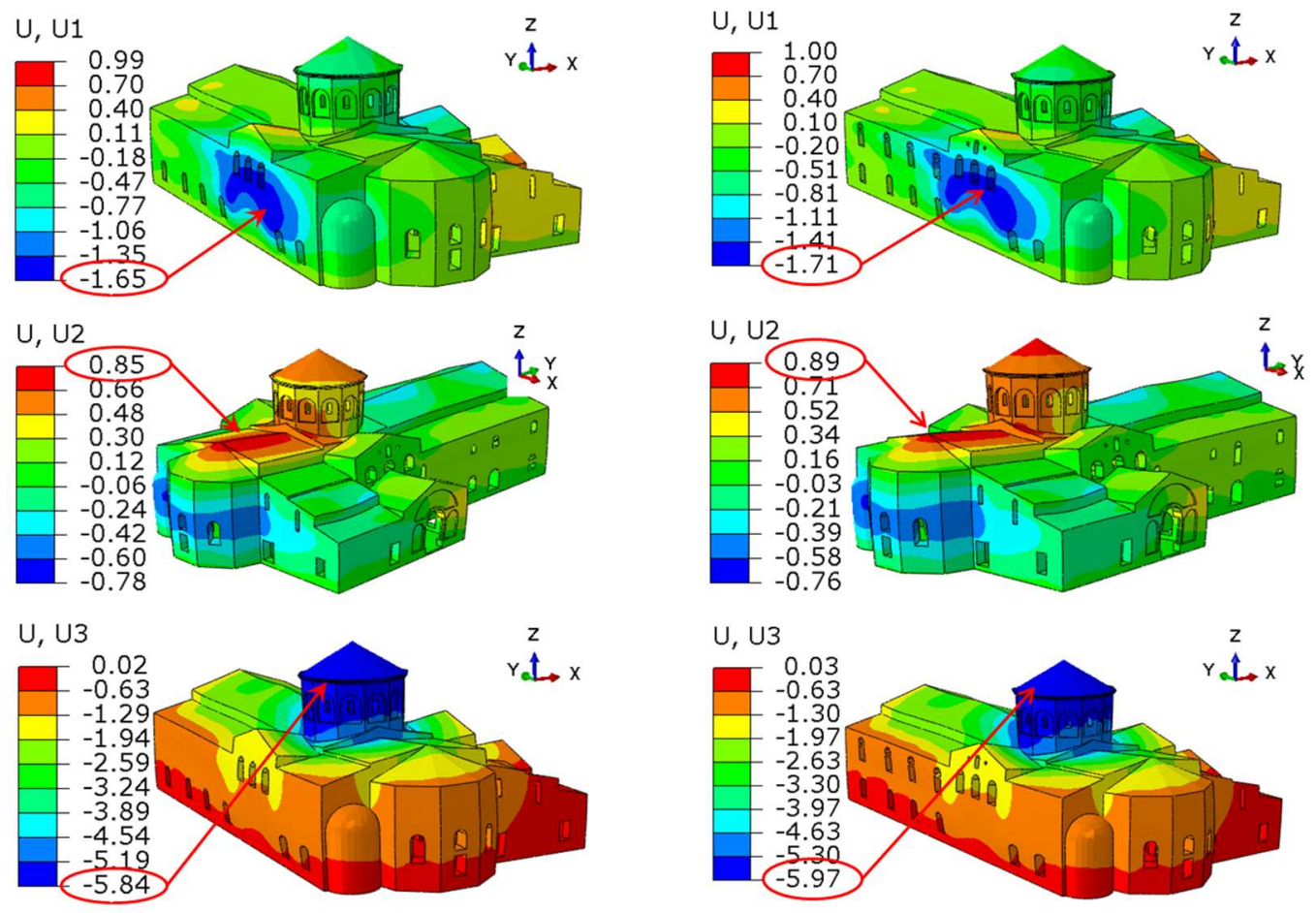

a) Without window openings

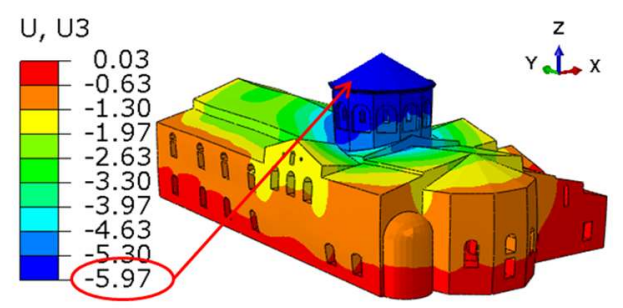

b) With window openings

Fig. 11. Static displacement propagations in transverse (U1), longitudinal (U2) and vertical (U3) directions

The minimum (compressive) and maximum (tensile) static principal stresses obtained when the window openings are blind and open are given in Figs. 12-13. When the window openings are blind, the maximum and minimum static principal stresses under the mosque's self weight and live 
loads are obtained as $0.51 \mathrm{MPa}$ and $1.23 \mathrm{MPa}$, respectively, near the bottom of columns. It can be seen from Fig. 4 that real damages occurred at the bottom of the columns. When the window openings exist, the maximum and minimum static principal stresses are determined as $0.53 \mathrm{MPa}$ and 1.24MPa, respectively. The maximum and minimum static principal stress values obtained in cases of with and without window openings are close to each other. However, as can be seen from Figs. 12-13, these values of maximum and minimum static principal stresses occur only in a small local region. The increment in stresses is mainly due to stress concentration at corners and finite element mesh refinment of this region. The maximum and minimum principal stresses occuring throughout the mosque are smaller. It is observed that the maximum principal static stress distributions increase in case of windows are open. However, the mimimum principal static stresses are close to each other in the case where the window openings are blind and open.

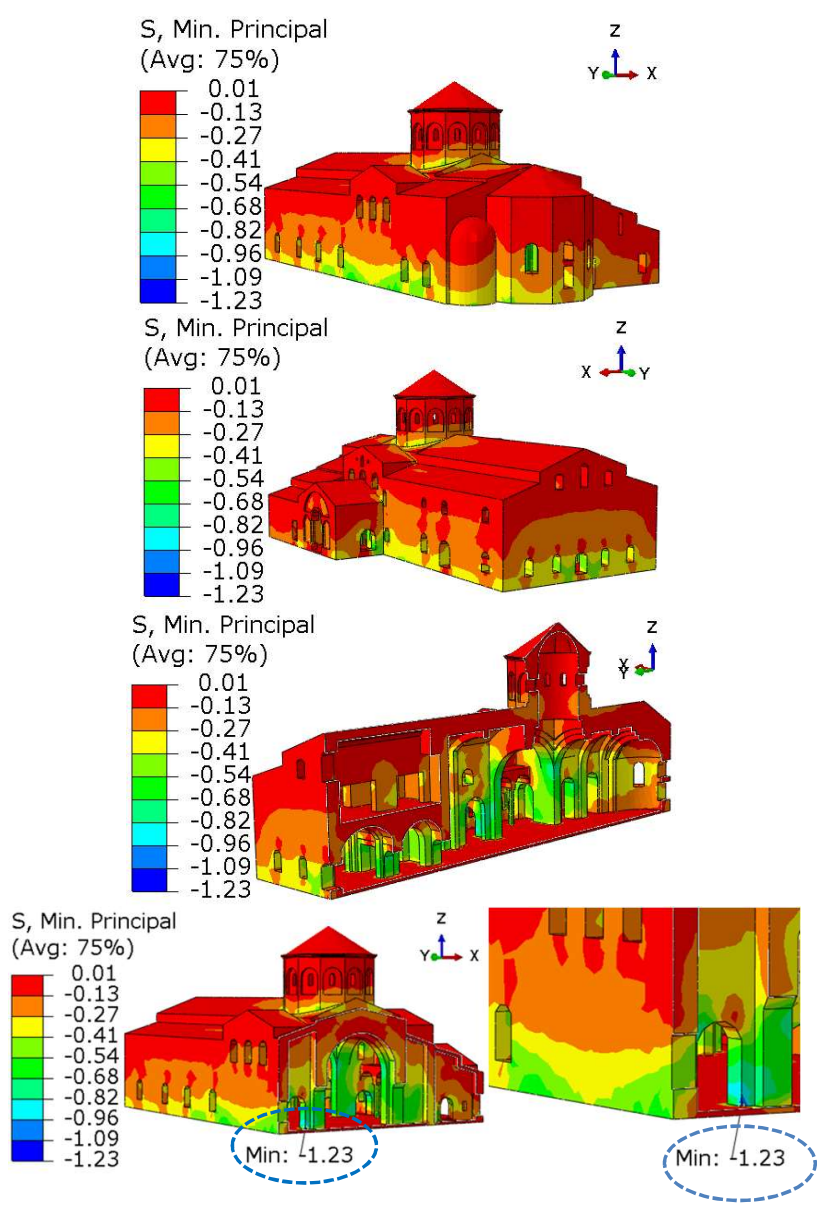

a)Without window openings
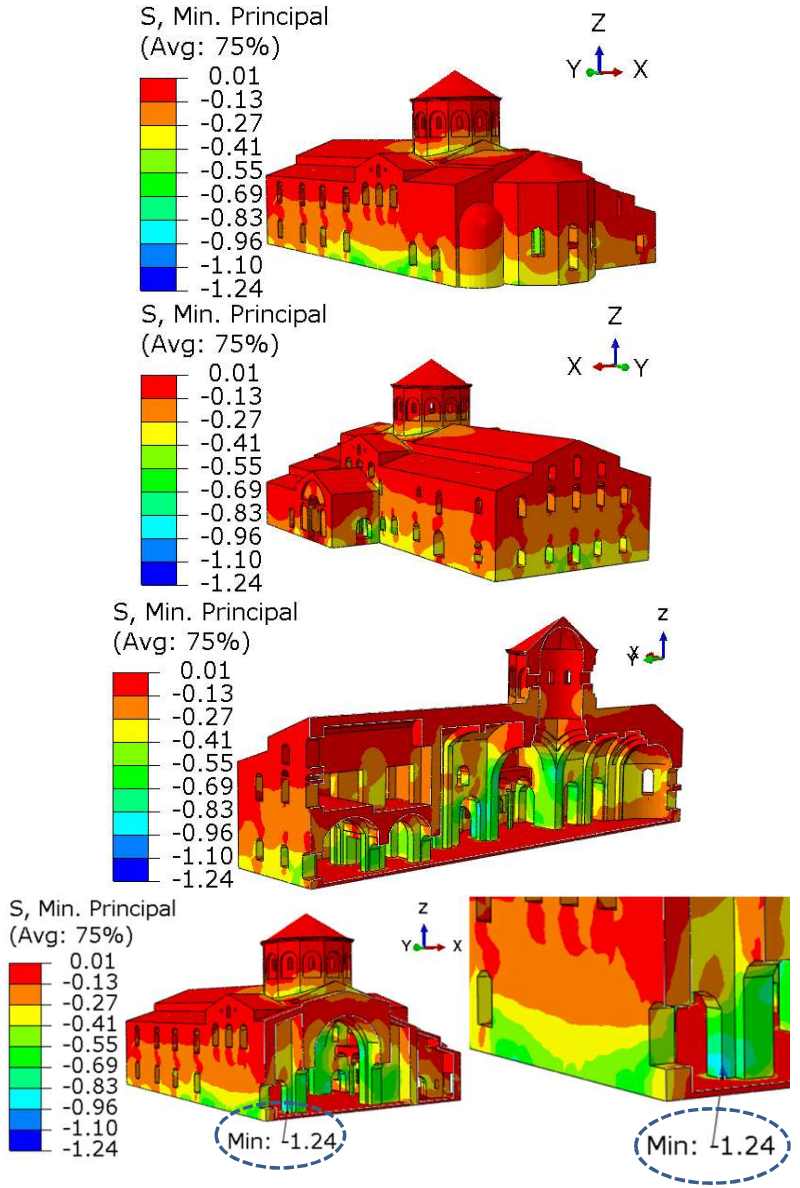

b) With window openings

Fig. 12. Propagations of minimum static principal stresses 


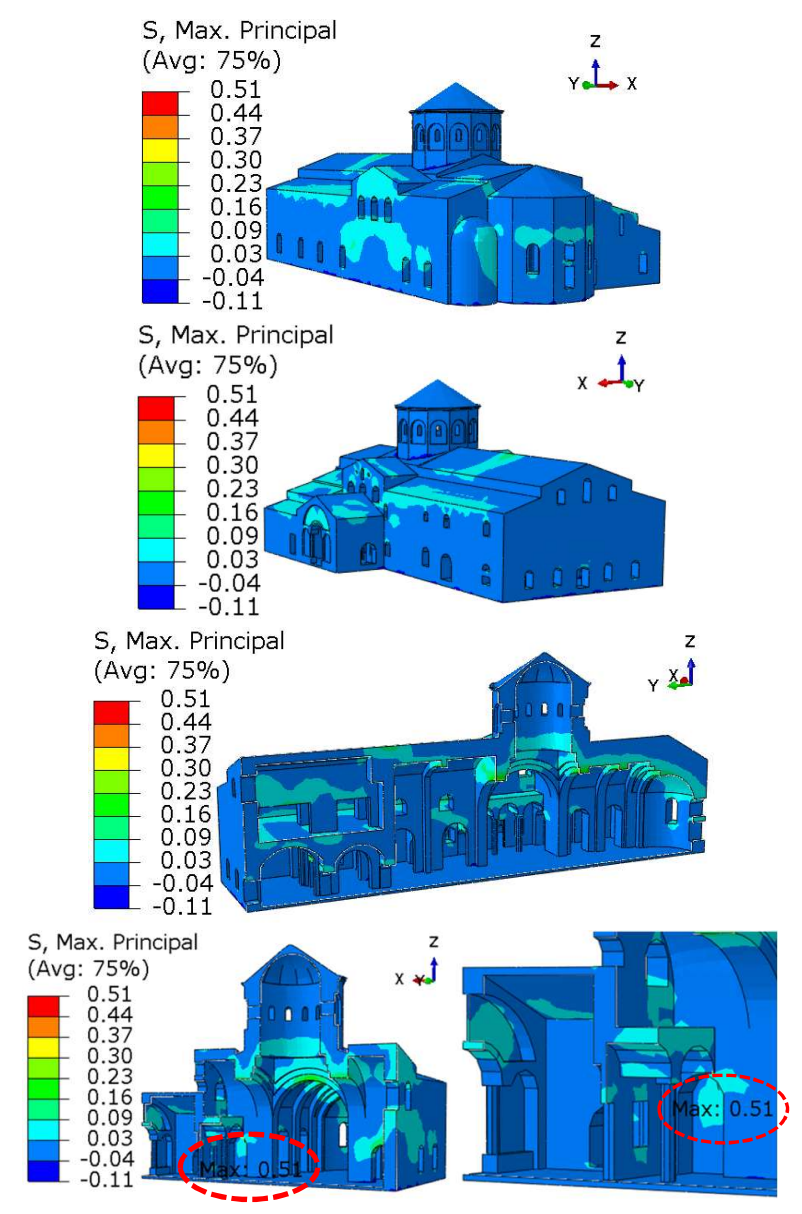

a)Without window openings
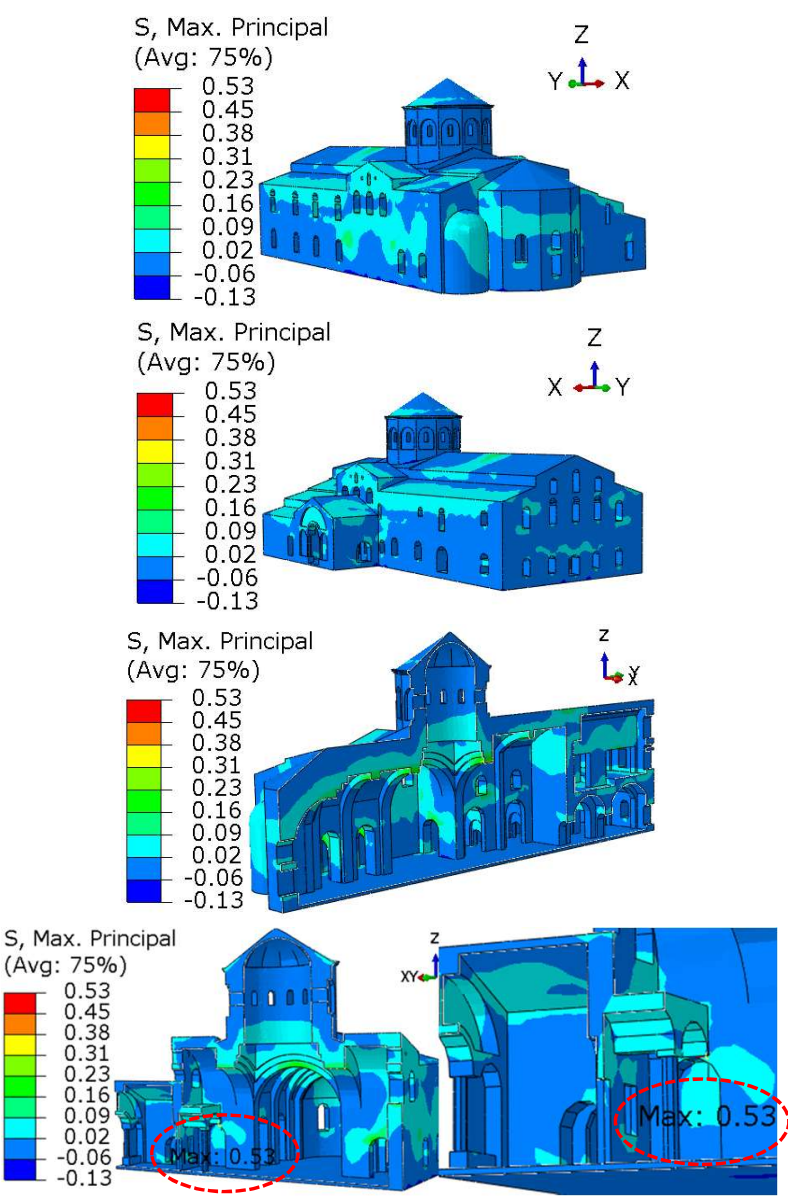

b) With window openings

Fig. 13. Propagations of maximum static principal stresses

Erzincan earthquake in 1992, which is the largest earthquake occurred nearest to Trabzon city is selected for the seismic analyses. Baseline corrected original acceleration records of the Erzincan earthquake in east-west (E-W), north-south (N-S) and vertical (U-D) directions are depicted in Fig. 14. The peak ground acceleration (PGA) values of the earthquake in east-west (E-W), northsouth (N-S) and vertical (U-D) directions are $449.96 \mathrm{~cm} / \mathrm{s}^{2}, 385.52 \mathrm{~cm} / \mathrm{s}^{2}, 192.164 \mathrm{~cm} / \mathrm{s}^{2}$, respectively. In the time history analysis, the first 10 seconds of the E-W, N-S and U-D acceleration components are simultaneously applied to the mosque model with and without window openings in the transverse (X-axis), longitudional ( $\mathrm{Y}$-axis) and vertical (Z-axis) directions, respectively. During earthquake analyses, self weight and $5 \mathrm{kN} / \mathrm{m}^{2}$ live load were taken into consideration with earthquake loads and step by step time integration technique are used. 

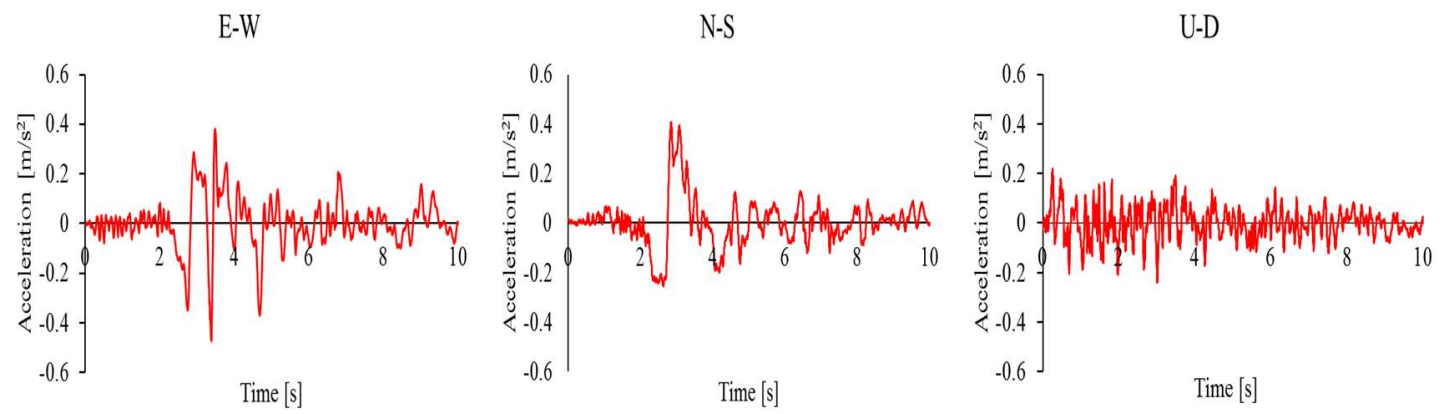

Fig. 14. Acceleration records of Erzincan eartquake (1992) in east-west (E-W), north-south (N-S) and vertical (U-D) directions (Web-2 (2017))

The maximum dynamic displacements and distributions of U1, U2, and U3 obtained in the transverse (X-axis), longitudinal ( $\mathrm{Y}$-axis) and vertical (Z-axis) directions from the finite element models with and without window opening are given in Fig. 15. The maximum dynamic transverse, longitudinal and vertical displacements were obtained as $49.8 \mathrm{~mm},-24.4 \mathrm{~mm}$ and $-12.7 \mathrm{~mm}$ in the case of blind windows; and $46.5 \mathrm{~mm}, 27.8 \mathrm{~mm}$ and $-14.3 \mathrm{~mm}$ in the case of openned windows, respectively. The maximum dynamic displacements occur on the dome. In the case of opening of the blind windows, a decrease in transverse displacement, an increase and direction change in longitudinal displacement, an increase in vertical displacement are observed. In addition, as can be seen from Fig. 15 that there is a change in the frequency contents of dynamic displacements and significant differences occur in the dynamic displacement distributions. The displacement time histories and occurrence times of peak values change with considering window openings during the earthquake. It can be also seen from the displacement colour contours in the mosque that displacement distributions change with opening windows.

The allowable roof drift limit for historical masonry structures recommended by TYDRYK (2017) is $0.3 \%$ of structure height. The maximum dynamic horizontal displacements in the transverse direciton in the case of with and without window openings are $0.0465 \mathrm{~m}$ and $0.0498 \mathrm{~m}$, respectively. The height of the mosque is $16.84 \mathrm{~m}$. The roof drifts of the mosque with and without window openings are calculated as 0.00276 and 0.00295 , respectively. The roof drift of the mosque with 
window openings is smaller than that of the mosque without window openings. Both calculated roof drift ratios very close to the allowable roof drift limit ratio of $0.3 \%$.
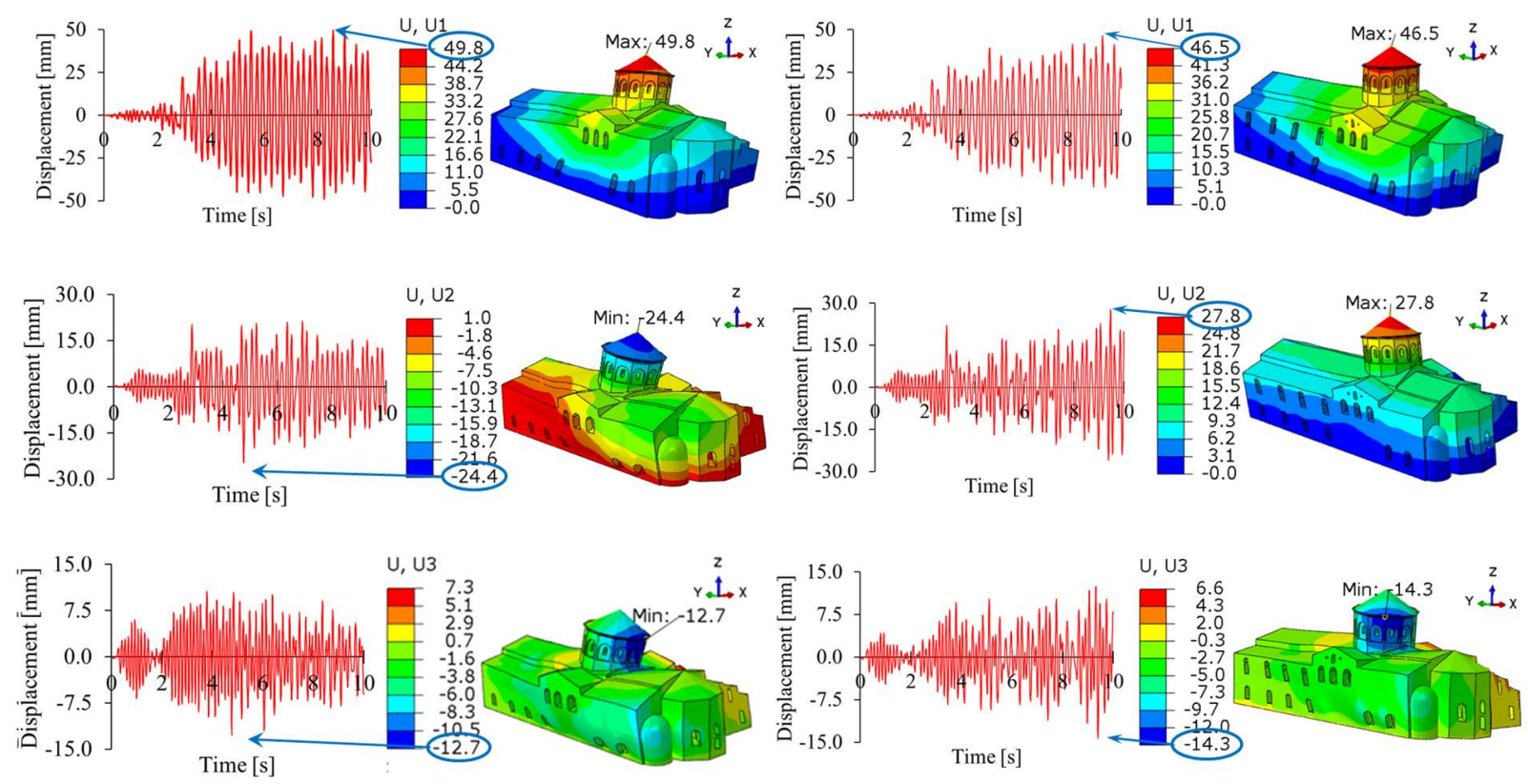

a) Without window openings

b) With window openings

Fig. 15. Time histories and propagations of dynamic displacement in transverse (U1), longitudinal (U2) and vertical (U3) directions

The minimum (compressive) and maximum (tensile) principal stresses obtained under self weight, live and earthquake loads are shown in Figs. 16 and 17 for blind and open window cases. The minimum and maximum principal stresses are calculated as $-7.79 \mathrm{MPa}$ and $1.95 \mathrm{MPa}$, respectively, in the case of blind windows. If the blind windows are open, the minimum and maximum principal stresses are obtained as $-7.48 \mathrm{MPa}$ and 1.62MPa. In Figs. 16 and 17, the minimum and maximum principal stresses were scaled according to the wall compressive $(6.1 \mathrm{MPa})$ and tensile strengths $(0.61 \mathrm{MPa})$, respectively. The minimum and maximum principal stresses occur at different times in the cases of blind and open windows. The regions where the maximum and minimum principal stress values are formed are shown in gray and black colors, respectively, in the stress distributions. In other words, the areas where the stresses exceeded the wall compressive and tensile strengths are shown black and gray colors, respectively. As can be seen from Fig. 16, in the cases of the 
blind and open windows, the minimum principal stress value only occurs in a localized zone and exceedes the wall compressive strength in this region. However, the maximum principal stresses exceed the wall tensile strength more widely in both blind and open window cases (Fig. 17). When the blind windows are opened, the maximum principal stress distributions with gray colors, which exceed the wall tensile strength, increase especially in the column elements bearing the dome, and the dome and body connection. The values of principal stress distributions in this regions show a significant increase from 0.61 to $1.95 \mathrm{MPa}$.

For general assessment of the maximum analyses results, the maximum values of displacements and stresses obtained under self weight and live; and self weight, live and earthquake loads are summarized in Table 5 in the cases of without window openings and with window openings. It can be seen from Table 5 that the maximum displacements and stresses in both window cases increase considerably when the earthquake loads are considered in the analyses. When the blind windows are opened, the maximum displacements determined under self weight and live loads in the transverse, longitudinal and vertical directions increase as $2.2 \%, 3.6 \%$ and $4.7 \%$, respectively. However, when the earthquake forces are included in the analyses, the maximum transverse displacement decreases by $6.6 \%$, the displacements in the longitudinal and vertical directions increase by $13.9 \%$ and $12.3 \%$, respectively. In the opened window case, the maximum compressive and tensile stresses obtained under self weight and live loads increase by $3.9 \%$ and $0.8 \%$, respectively. However, the maximum compressive and tensile stresses obtained under self weight, live and earthquake loads decrease by $4 \%, 17 \%$, respectively.

Table 5. Maximum displacements and stresses under static and earthquake loads

\begin{tabular}{cccccccccccc}
\hline \hline \multirow{2}{*}{$\begin{array}{c}\text { Window Opening } \\
\text { Cases }\end{array}$} & \multicolumn{3}{c}{$\begin{array}{c}\text { Displacement }(\mathrm{mm}) \\
\text { under static loads }\end{array}$} & \multicolumn{4}{c}{$\begin{array}{c}\text { Displacement }(\mathrm{mm}) \\
\text { under static and } \\
\text { earthquake loads }\end{array}$} & \multicolumn{2}{c}{$\begin{array}{c}\text { Stresses (MPa) under static } \\
\text { loads }\end{array}$} & $\begin{array}{c}\text { Stresses (MPa) under static } \\
\text { and earthquake loads }\end{array}$ \\
\cline { 2 - 12 } & Tran. & Lon. & Ver. & Tran. & Lon. & Ver. & Comp. & Tensile & Comp. & Tensile \\
\hline $\begin{array}{c}\text { Without window } \\
\text { openings }\end{array}$ & 5.84 & 1.65 & 0.85 & 49.8 & -24.4 & -12.7 & 1.23 & 0.51 & 7.79 & 1.95 \\
$\begin{array}{c}\text { With window } \\
\text { openings }\end{array}$ & 5.97 & 1.71 & 0.89 & 46.5 & 27.8 & -14.3 & 1.24 & 0.53 & 7.48 & 1.62 \\
\hline \hline
\end{tabular}




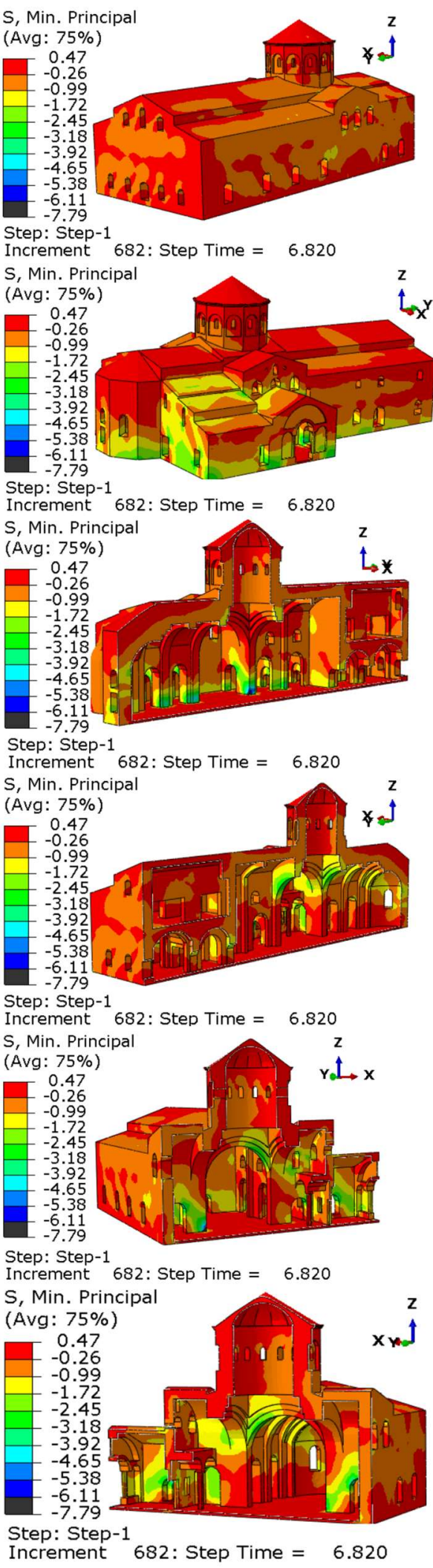

a) Without window openings

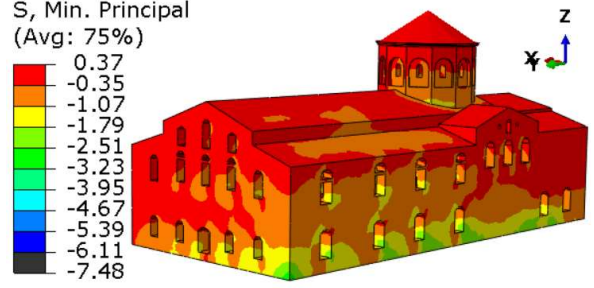

Step: Step-1

Increment 982: Step Time $=9.820$

$\mathrm{S}$, Min. Principal

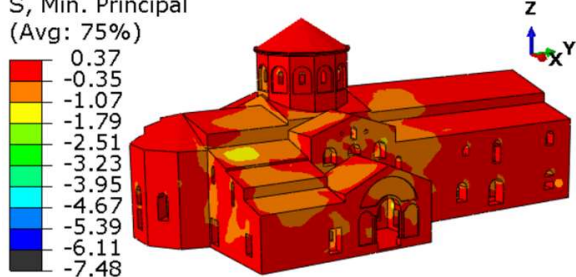

Step: Step-1

Increment 982: Step Time $=9.820$

$S$, Min. Principal

(Avg: $75 \%$ )

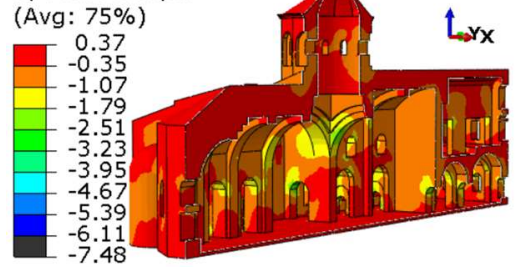

Step: Step-1

Increment 982: Step Time $=9.820$

S, Min. Principal

(Avg: $75 \%$ )

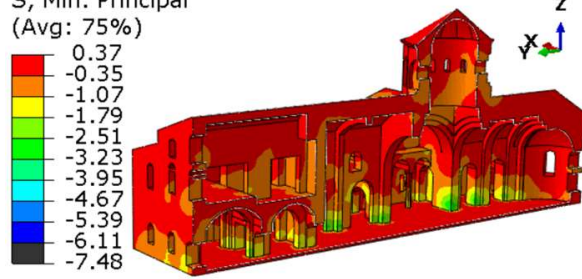

Step: Step-1

Increment 982: Step Time $=9.820$

(Avg: 75\%)

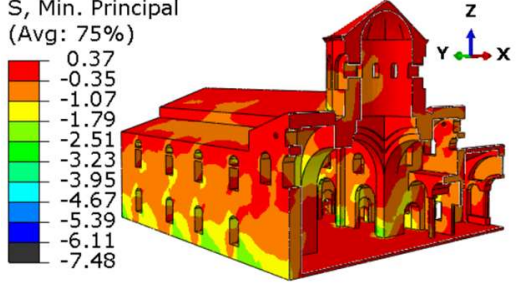

Step: Step-1

Increment 982: Step Time $=9.820$

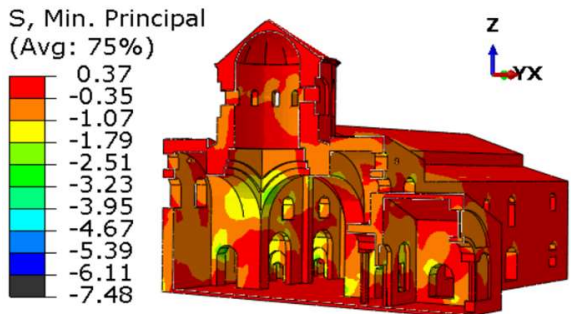

Step: Step-1

Increment 982: Step Time $=9.820$

b) With window openings

Fig. 16. Propagations of minimum principal stresses under self weight, live and earthquake loads 


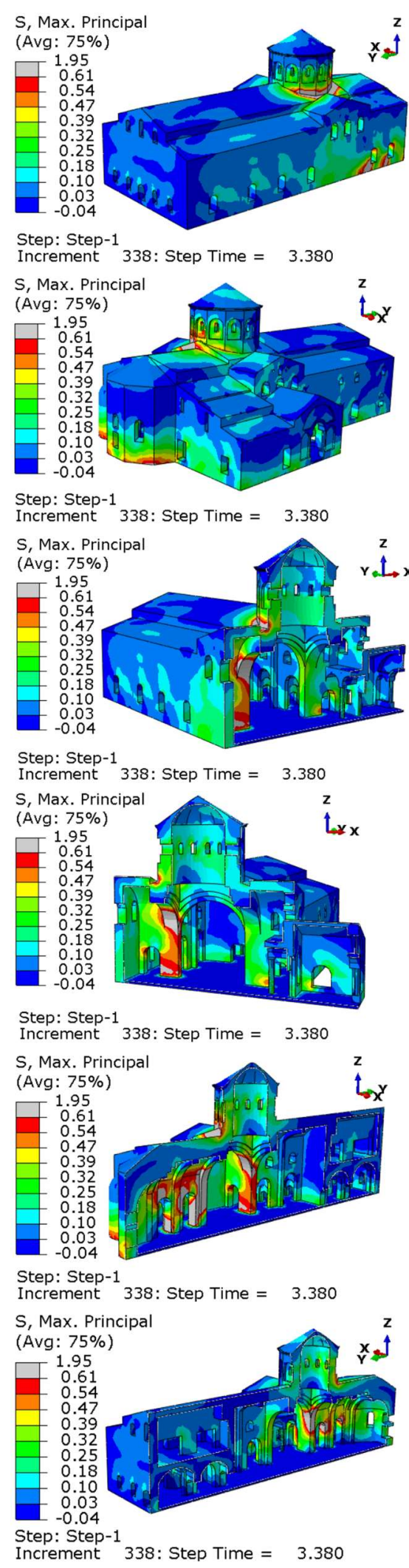

a)Without window openings

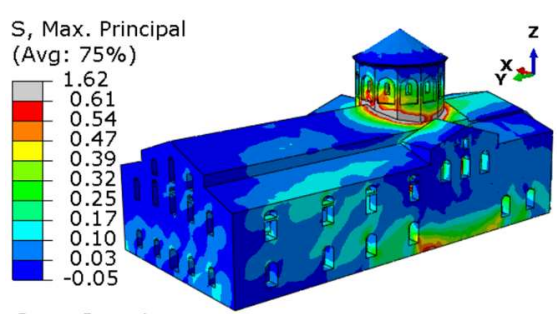

Step: Step-1

Increment 338: Step Time $=3.380$

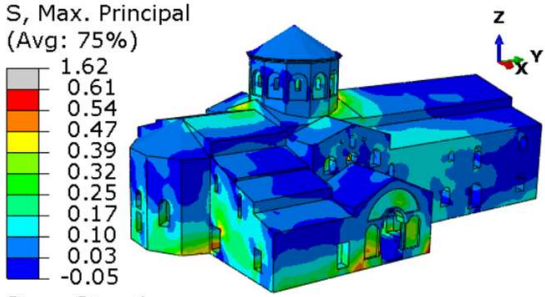

Step: Step-1

Increment 338: Step Time $=3.380$

S, Max. Principal

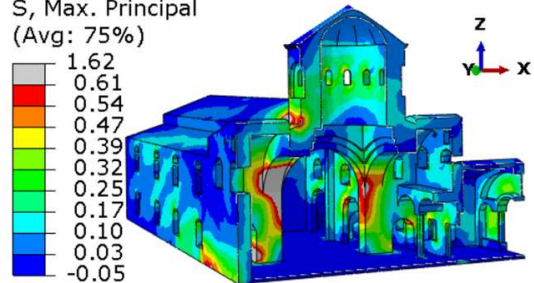

Step: Step-1

Increment $338:$ Step Time $=3.380$

S, Max. Principal

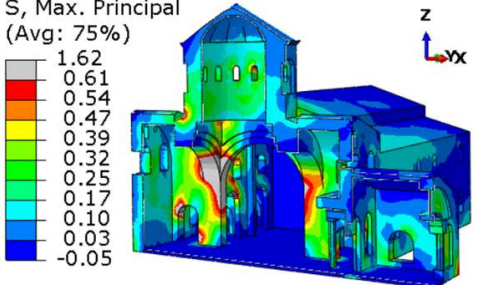

Step: Step-1

Increment 338: Step Time $=3.380$

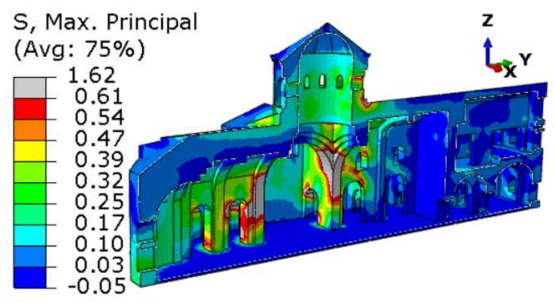

Increment 338: Step Time $=3.380$

S, Max. Principal

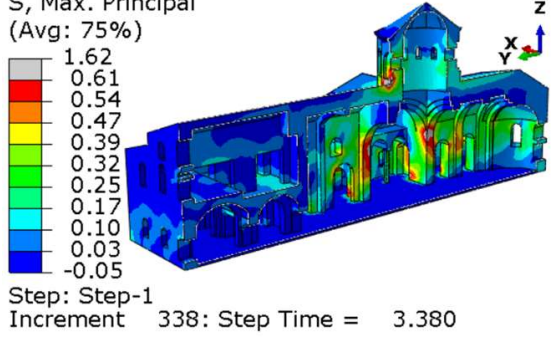

b) With window openings

Fig. 17. Propagations of maximum principal stresses under self weight, live and earthquake loads 


\section{Conclusions}

The window opening effects on static and seismic behaviors of historical masonry Fatih Mosque, which is under the restoration works, built in 914 in Trabzon, Turkey are investigated in this paper. The finite element model of the mosque is calibrated and validated using experimental dynamic characteristics obtained from the ambient vibration tests. The specific and general conclusions drawn from the analyses of the mosque with and without 12 blind windows are summarized below:

- Opening of the blind windows in the walls of the Fatih mosque slightly increases the static displacement by an average of $3.5 \%$ in three directions considered.

- In the case of opening of the blind windows, the maximum dynamic transverse displacement decreases by $6.6 \%$ whereas the dynamic displacements in the longitudinal and vertical directions increase by $13.9 \%$ and $12.3 \%$, respectively compared with the case of blind windows. The displacement time histories and occurrence times of peak values change when considering window openings during the earthquake.

- The roof drifts of the mosque with and without window openings are obtained as $0.276 \%$ and $0.295 \%$ of the mosque height, respectively. Both roof drift ratios are very close to the allowable roof drift limit ratio of $0.3 \%$ recommended by TYDRYK (2017).

- Maximum displacements and stresses in blind and open window cases considerably increase when the earthquake loads are added to the self weight and live loads.

- The minimum (compressive) and maximum (tensile) static principal stress values obtained in cases of with and without window openings increase by $3.9 \%$ and $0.8 \%$, respectively but do not exceed strength of the walls. It is also observed that the maximum principal static stress distributions of the mosque walls increase in the case of openned windows. However, the minimum principal static stress distributions are close to each other in both window cases. 
- Under self weight, live and earthquake loads, the minimum (compressive) and maximum (tensile) principal stresses obtained in cases of with and without window openings decreases by $4 \%$ and $17 \%$, respectively. The minimum (compressive) principal stress values only exceedes the wall compressive strength in a localized zone in both blind and open window cases. However, the maximum principal stresses exceed the wall tensile strength in larger areas in both blind and open window cases. The maximum principal stress distributions increase with considering window openings. The increase in maximum principal stresses distributions are particularly observed in column elements supporting the dome, and dome connection with the mosque walls. Besides, it is observed that the minimum and maximum principal stresses occur at different times in the cases of blind and open windows.

It can be generally concluded that window opening interventions to the structural walls of historical mosques and churches should be carefully decided according to the experimental and numerical studies.

\section{Acknowledgments}

The authors would like to express sincere thanks to Regional Directorate of Foundation in Trabzon, Turkey for their contributions.

\section{References}

- Abaqus V13. 2010. Dassault Systèmes Simulia Corp. Providence, Rhode Island, USA.

- Altunişik, A.C., A. Bayraktar, and A.F. Genç. 2016. A study on seismic behaviour of masonry mosques after restoration. Earthquakes and Structures (10): 1331-1346.

- Arêde, A., A. Costa, D. Moreira, and N. Neves .2012. Seismic analysis and strengthening of Pico Island Churches. Bull. Earthq. Eng.10(1): 181-209. 
- Aslan, A., and A. Sahin. 2016. Seismic behavior evaluation of Suleymaniye mosque under different earthquake records. Disaster Science and Engineering 2(2): 67-75.

- Art History Report. 2014. Art History of Fatih Mosque. Directorate Regional of Foundations, Trabzon, Turkey (in Turkish).

- Berilgen, M.M. 2007. Evaluation of local site effects on earthquake damages of Fatih Mosque. Engineering Geology 91(2-4): 240-253.

- Betti, M., and A.Vignoli. 2008a. Modelling and analysis of a Romanesque church under earthquake loading: assessment of seismic resistance. Eng. Struct. 30(2): 352-367.

- Betti, M., and A.Vignoli. 2008b. Assessment of seismic resistance of a basilica-type church under earthquake loading: modelling and analysis. Adv Eng Softw 39(4): 258283.

- Betti, M., and A. Vignoli. 2011. Numerical assessment of the static and seismic behaviour of the basilica of Santa Maria all'Impruneta (Italy). Constr Build Mater 25(12): 4308-4324.

- Cagnan, Z. 2012. Numerical models for the seismic assessment of St. Nicholas Cathedral, Cyprus. Soil Dynamics and Earthquake Engineering 39: 50-60.

- Çakır, F., B.S. Seker, A. Durmus, A. Dogangün, and H. Uysal. 2015. Seismic assessment of a historical masonry mosque by experimental tests and finite element analyses. $K S C E$ Journal of Civil Engineering 19 (1):158-164.

- Calik, I., A. Bayraktar, and T. Turker. 2016. Determination of the effect on the dynamic behaviour of historical masonry mosques reinforced concrete domes by ambient vibration testing. Journal of The Faculty of Engineering and Architecture of Gazi University 31 (3): $622-631$. 
- Calik, I., A. Bayraktar, T. Türker, and A.O. Ayan. 2017. Dynamic identification of historical Molla Siyah mosque before and after restoration. Res. Eng. Struct. Mat. 3(3): 164-175.

- Demir, A., H. Nohutcu, E. Ercan, E. Hokelekli, and G. Altintas. 2016. Effect of model calibration on seismic behaviour of a historical mosque. Structural Engineering and Mechanics 60: 749-760.

- Eurocode 6. 1996. Design of Masonry Structures. European Union.

- Jorquera, N., G. Misseri, N. Palazzi, L. Rovero, and U. Tonietti. 2017. Structural characterization and seismic performance of San Francisco Church, the Most Ancient Monument in Santiago, Chile. International Journal of Architectural Heritage 11(8): 1061-1085.

- Karaton, M., and H.S. Aksoy. 2018. Seismic damage assessment of an 891 years old historic masonry mosque. Periodica Polytechnica Civil Engineering 62(1): 126-135,

- Koseoglu, G.C. 2011. Investigation of a damaged historical mosque with finite element analysis. MSc Thesis, Middle East Technical University, Ankara, Turkey.

- Koseoglu, G.C., and E. Canbay. 2015. Assessment and rehabilitation of the damaged historic Cenabı Ahmet Pasha Mosque. Engineering Failure Analysis 57: 389-398.

- Lagomarsino, S. 2012. Damage assessment of churches after L'Aquila earthquake (2009). Bull. Earthq. Eng. 10 (1): 73-92.

- Material Report. 2013. Historical Masonry Fatih Mosque. Regional Directorate of Foundations, Trabzon, Turkey (in Turkish).

- Milani, G., and M. Valente. 2015a. Failure analysis of seven masonry churches severely damaged during the 2012 Emilia-Romagna (Italy) earthquake: non-linear dynamic analyses vs conventional static approaches. Eng. Fail. Anal. 54: 13-56. 
- Milani, G., and M. Valente. 2015b. Comparative pushover and limit analyses on seven masonry churches damaged by the 2012 Emilia-Romagna (Italy) seismic events: possibilities of non-linear finite elements compared with pre-assigned failure mechanisms. Eng. Fail. Anal. 47: 129-161.

- Nohutcu, H., A. Demir, E. Ercan, E. Hökelekli, and G. Altıntas. 2015. Investigation of a historic masonry structure by numerical and operational modal analyses. The Structural Design of Tall and Special Buildings. 24 (13): 821-834.

- Pluijm, van der R. 1999. Out-of-plane bending of masonry: behaviour and strength. PhD Thesis, Technische Universiteit Eindhoven, Eindhoven.

- Portioli, F., O. Mammana, R. Landolfo, F.M. Mazzolani, L. Krstevska, L. Tashkov, and K. Gramatikov. 2011. Seismic Retrofitting of Mustafa Pasha Mosque in Skopje: Finite Element Analysis, Journal of Earthquake Engineering 15(4): 620-639.

- Restoration Project. 2014. Fatih Mosque. Directorate Regional of Foundations, Trabzon, Turkey.

- Rossi, M., S. Cattari, and S. Lagomarsino. 2015. Performance-based assessment of the Great Mosque of Algiers. Bulletin of Earthquake Engineering 13 (1): 369-388.

- Seker, S.S., F. Cakir, A. Dogangun, and H. Uysal. 2014. Investigation of the structural performance of a masonry domed mosque by experimental tests and numerical analysis, Earthquakes and Structures 6(4): 335-350.

- $\quad$ TS 498. 1997. Design Loads for Buildings. Turkish Standard Institute, Ankara, Turkey (in Turkish).

- TYDRYK. 2017. Tarihi Yapilar için Deprem Risklerinin Yönetimi Kilavuzu. General Directorate of Foundation, Ankara, Turkey (in Turkish). 
- TDY. 2007. Specification for Buildings to be Built in Seismic Zones. Ministry of Public Works and Settlement, Ankara, Turkey.

- Tzanakis, M.J., G.A. Papagiannopoulos, and G.D. Hatzigeorgiou. 2016. Seismic response and retrofitting proposals of the St. Titus Chruch. Earthquakes and Structures 10 (6): 13471367.

- Valente, M., G. Barbieri, and L. Biolzi. 2017a. Seismic assessment of two masonry Baroque churches damaged by the 2012 Emilia earthquake. Engineering Failure Analysis 79: $773-802$.

- Valente, M., G. Barbieri, and L. Biolzi. 2017b. Damage assessment of three medieval churches after the 2012 Emilia earthquake. Bulletin of Earthquake Engineering 15 (7): 2939-2980.

- Web-1, Republic of Turkey Prime Ministry Disaster \& Emergency Management Authority, $\quad$ http://www.deprem.gov.tr/en/Category/earthquake-zoning-map-96531 (accessed November 8, 2017).

- Web-2, Strong Ground Motion Database of Turkey, http://kyhdata.deprem.gov.tr/2K/kyhdata_v4.php (accessed November 8, 2017). 